Photogallery

\title{
Simultaneous spawning of Pocillopora and Goniopora corals in the morning time
}

\section{Go SUZUKI*}

Ishigaki Tropical Station, Seikai National Fisheries Research Institute, Fisheries Research Agency, 148-446 Fukai-Ota, Ishigaki, Okinawa 907-0451, Japan

* Corresponding author: G. Suzuki

E-mail: gosuzu@fra.affrc.go.jp

Communicated by Hiroya Yamano (Editor-in-Chief)

Keywords Daytime spawning, Gonochoric coral, Reproductive behavior

In the morning (9:00) of 18 June 2011 (sunrise: 5:55, sunset: 19:34), the simultaneous spawning of two distantly related species of scleractinian corals was observed in Ishigaki Island $\left(24^{\circ} 27^{\prime} 38^{\prime \prime} \mathrm{N}, 124^{\circ} 12^{\prime} 20^{\prime \prime} \mathrm{E}\right)$, the southernmost region of Ryukyu Islands, Japan. The observed species were the hermaphroditic spawner Pocillopora verrucosa and the gonochoric spawner Goniopora djiboutiensis (Fig. 1). Morning-time spawning of Goniopora corals is the first record in the world. Both male (ejected sperms) and female (ejected eggs) Goniopora colonies were found within a single ridge at the reef slope (Fig. 2). Although a broad survey could not be conducted, at least 5 or 6 colonies ejecting sperms or eggs were found along a few ridges. Small fishes such as damselfish aggregated around spawned colonies, suggesting that they might feed on the eggs and sperms of corals.

Most scleractinian corals spawn during night-time, such as the mass spawning of Acropora corals (e.g., Babcock et al. 1986). Recently, there are some reports on corals spawning at daytime. Thus far, it is known that Porites rus released sperm in the noon in Chumbe Island in Zanzibar, Western Indian Ocean (Bronstein and Loya 2011), Diploria labyrinthiformis spawns just before sunset in the Caribbean (Muller and Vermeij 2011), and Goniastrea australensis spawns in the afternoon (16:00-17:00) in the Great Barrier Reef (Kojis and Quinn 1981). Moreover, P. verrucosa and P. eydouxi spawn (first

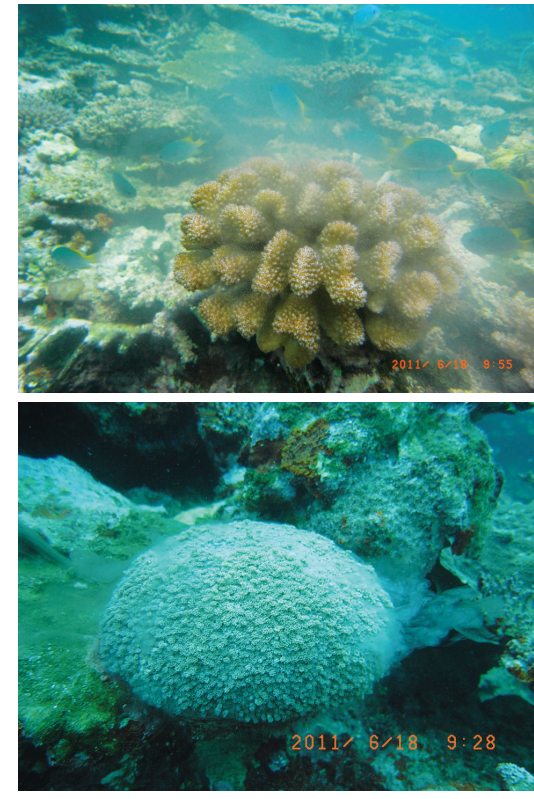

Fig. 1 Pocillopora verrucosa (upper) and Goniopora djiboutiensis (lower) ejecting sperm in the late morning in Tomino Reef, Ishigaki Island released sperm and then negatively buoyant eggs) in the early morning (approximately $1 \mathrm{~h}$ after sunrise) in Okinawa, mainland of Ryukyu Islands (Kinzie 1993, Hirose et al 2000) and also the central Red Sea (Bouwmeester et al. 2011). In other gonochoric spawners, Pavona sp. also spawned (ejecting only sperms) in the noon in the Gulf of Thailand (Plathong et al. 2006), and Pavona decussata spawned just 1-2 hours before sunrise in Kochi (Mezaki unpublished data), respectively. Although P. damicornis has different reproductive manners 
(e.g. Ward 1992), only spawning in the early morning (3:00-5:00) was observed. Moreover, in Goniopora, although the spawning of G. lobata just before sunset (18:00-19:00) (Kushimoto, Japan; Woesik 1995) and just after sunset (Lizard Island, Great Barrier Reef; Babcock et al. 1986) have been reported, no spawning in the late morning ( $>3 \mathrm{~h}$ after sunrise) was observed in any regions. In addition, this is the first report in the literature on synchronous daytime spawning of hermaphroditic and gonochoric corals.

These observations suggest that the spawning time of scleractinian corals is likely to be more flexible than previously thought, especially in gonochoric corals (or all corals except bundle spawners). The spawning time is a key factor in the speciation of sessile and simultaneous spawning organisms. This report found that two genetically distant species (see Fukami et al. 2008),

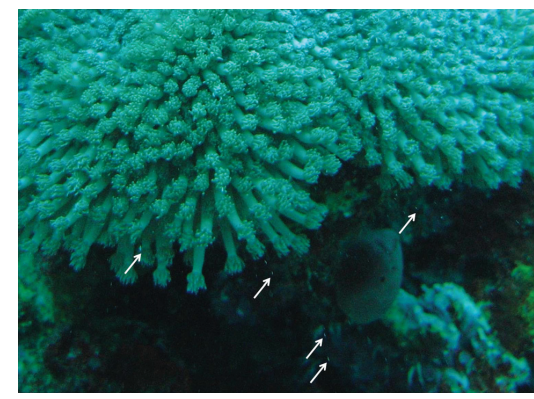

Fig. 2 Goniopora djiboutiensis female colony ejecting eggs (allow head) at the same time with ejecing sperm by a male colony (Fig. 1). which have no probability of crossing each other, spawned simultaneously along a single ridge, suggesting that the daytime spawning of scleractinian corals synchronizes not only between close related species via inter-colony signals but also between distant species probably because of intra-colony cue such as duration after sunrise or sunset that was genetically determined.

\section{References}

Babcock RC, Bull GD, Harrison PL, Heyward AJ, Oliver JK, Wallace CC, Willis BL (1986) Synchronous spawnings of 105 scleractinian coral species on the Great Barrier Reef. Mar Biol 90: 379-394

Bouwmeester J, Berumen ML, Baird AH (2011) Daytime broadcast spawning of Pocillopora verrucosa on coral reefs of the central Red Sea. Galaxea J Coral Reef Studies 13: 23-24

Bronstein O, Loya Y (2011) Daytime spawning of Porites rus on the coral reefs of Chumbe Island in Zanzibar, Western Indian Ocean (WIO). Coral Reefs 30: 441

Fukami H, Chen CA, Budd AF, Collins A, Wallace C, Chuang YY, Chen C, Dai CF, Iwao K, Sheppard C, Knowlton N (2008) Mitochondrial and nuclear genes suggest that stony corals are monophyletic but most families of stony corals are not (order Scleractinia, class Anthozoa, phylum Cnidaria). Plos One 3: e3222

Hirose M, Kinzie III RA, Hidaka M (2000) Early development of zooxanthella- containing eggs of the corals Pocillopora verrucosa and P. eydouxi with special reference to the distribution of zooxanthellae. Biol Bull 199: 68-75

Kinzie RA (1993) Spawning in the reef corals Pocillopora verrucosa and Pocillopora eydouxi at Sesoko Island, Okinawa. Galaxea 11: 93-105

Kojis BL, Quinn NJ (1981) Aspects of sexual reproduction and larval development in the shallow water hermatipoc coral, Goniastrea australensis (Edwards and Haime, 1857). Bull Mar Sci 31: 558-573

Muller E, Vermeij MJA (2011) Day time spawning of a Caribbean coral. Coral Reefs 30: 1147

Plathong S, Chanmethakul T, Suwonno V, Buaphet P, Baird AH, Chen CA, Soontornpitakkool S (2006) Daytime gamete release from the reef-building coral, Pavona sp., in the Gulf of Thailand. Coral Reefs 25: 72

Ward S (1992) Evidence for broadcast spawning as well as brooding in the scleractinian coral Pocillopora damicornis. Mar Biol 112: 641-646

Woesik R (1995) Coral communities at high latitude are not pseudopopulations: evidence of spawning at $32^{\circ} \mathrm{N}$, Japan. Coral Reefs 14: 119-120

Received: 27 April 2012/Accepted: 22 November 2012

(C) Japanese Coral Reef Society 